\title{
Using Daphnia magna Straus to monitor toxicity of sustainable oil sludge bio-phytoremediation
}

\author{
Nia Rossiana $^{1}$, Keukeu Kaniawati Rosada ${ }^{1}$, Monica Natasha Almapangesti ${ }^{1}$, Yayat Dhahiyat $^{2}$ \\ ${ }^{1}$ Department Biology Faculty of Mathematic and Natural Sciences University of Padjadjaran \\ ${ }^{2}$ Department Fisheries Faculty of Fisheries and Marine Sciences University of Padjadjaran
}

\begin{abstract}
Oil sludge (OS) is the toxic product of various oil refinery processes. Oil sludge biophytoremediation is sustainable remediation efforts were conducted to reduce OS toxicity level and they also need to be monitored through toxicity test. In this study, the toxicants were OS postbiophytoremediation for 24 months $\left(\mathrm{OS}_{24}\right)$ and 40 months $\left(\mathrm{OS}_{40}\right)$, and were tested to Daphnia magna. The toxicity test consisted of Range Finding Test, acute and chronic toxicity test. The purpose of this research is to obtain the $\mathrm{LC}_{50}$ value of each OS and the chronic effects shown by D. magna. The method in this study was experimental with Completely Randomized Design (CRD). The LC $50-96$ hours values were calculated from $50 \%$ of dead individuals while $\mathrm{D}$. magna reproduction was calculated from the number of neonates (offspring) produced within three weeks. The $\mathrm{LC}_{50}$ of $\mathrm{OS}_{24}$ and $\mathrm{OS}_{40}$ were $0.042 \mathrm{ppm}$ and $0.366 \mathrm{ppm}$ respectively. Both were categorized as 'extremely toxic' refer to Swan, 1994, observed chronic effects were reproduction delays and a decrease in the number of neonates.
\end{abstract}

\section{INTRODUCTION}

Biophytoremediation is Green Sustainable Technology for Industrial Waste Management. Oil sludge is a waste derived from the petroleum industry and includes hazardous and toxic substances that must be biologically managed. One of the efforts to overcome oil sludge waste is by using bioremediation.Oil sludge (OS) is the toxic product of various oil refinery processes that is encountered during crude oil refining, refinery-wastewater treatment and cleaning of oil storage vessels [15]. Oil sludge contains viscous mixture of water, oil, sediments and high concentrations of hydrocarbon. The main composition of oil sludge are benzene, toluene, ethylbenzene, xylene and heavy metal such as lead $(\mathrm{Pb})$.

Taking into consideration, the thick and viscous form of OS can also harm living organisms in the contaminated area. The negative impacts of OS contamination must be observed in order to determine the valid management step. Oil sludge in soils pose a risk of leaching or the separation process of soluble (solute) and insoluble substances (inert) through the hydrological cycle. Solute substances will eventually reside in the aquatic ecosystem and cover water surfaces. As a result, sunlight cannot penetrate the water body which leads to a decrease in the rate of photosynthesis. Furthermore, the chemical compounds of oil sludge can accumulate in aquatic organisms' tissues and the buildup of these hazardous materials can travel through the food chain which will then be harmful for humans to consume any of those aquatic animals. This process is called biomagnification. These consequences will be society's health issue.
According to the Ministry of Environment Decree No. 128/2003, petroleum waste and contaminated soil should be treated biologically as an alternative of waste treatment technology. Bioremediation utilizes bacteria, fungi, macroalgae, microalgae, plants and animals. [10] made a combination of Pseudomonas aeruginosa and Bacillus sphaericus as bioremediators, along with the mycorrhizal plant Paraserianthes falcataria as a phytoremediator. Therefore, the whole process is called biophytoremediation. The mixture is composed of $40 \%$ oil sludge, $40 \%$ soil and $20 \%$ sand which had been composted by bacteria for 2 months. Afterwards, the OS mixture was planted with mycorrhizal plant for 40 months.

Monitoring the toxicity rate of oil sludge postbiophytoremediation is necessary to measure how much time is required for biophytoremediation processes to reduce the toxicity rate to zero or until it becomes nontoxic. The monitoring is carried out biologically so it is called biomonitoring, with a goal to evaluate the water body conditions [4]. Therefore, biomonitoring using post-biophytoremediation of oil sludge is carried out in this research for 24 and 40 months to evaluate the decrease in toxicity rate. The toxicity in this research is determined by $\mathrm{LC}_{50}$ or Lethal Concentration 50, i.e. the term used to define the concentration that kills $50 \%$ population of test biota at one time exposure for 24,48 , 72 , or 96 hours [7]. The research begins with preliminary test or Range Finding Test (RFT) to determine the range concentration of oil sludge that would be used for acute and chronic tests. The range was obtained by testing widely-spaced sample dilutions in a logarithmic series to D. magna; it is the range between the upper and lower limit that kills $50 \%$ of $D$. magna 
population during the 24-hour test. For each oil sludge sample of 24 and 40 months, they were diluted into 5 concentrations within the tested range using a logarithmic scale interval series table in accordance to [9]. These series of concentrations were used as the sample concentration for the acute toxicity test using $\mathrm{LC}_{50}$. The test animals were exposed to the diluted oil sludge sample for 96 hours and the number of animals of each test concentration were measured every 24 hours. The chronic test was carried out after the acute test. The parameter was the amount of offsprings produced from each concentration for 14 days.

The toxicity of oil sludge post-biophytoremediation must be tested to various organism levels (a.k.a multilevel organisms) and it will reveal different results between aquatic or terrestrial, and vertebrate or invertebrate animals. This process is called biomonitoring. To monitor the ecosystem's condition, biomonitoring uses organisms in which their viability can represent changes in water body quality. This group of animals is called bioindicator. If there is a correlation between the existence of one group of animals in nature with the ecosystem's condition, they can be considered as bioindicators [13]. In this study, the test animals were Daphnia magna which belongs to the class Branchiopoda. This species is often used in the fields of ecotoxicity because of its sensitivity. They show postexposure effects to toxicants such as a change in heartbeat, immobility, reproduction cycle, and even death [12]. Thus, D. magna is the ideal test animal for toxicity test with oil sludge as the toxicant, using the [5, 16] guidelines.

\section{MATERIALS AND METHODS}

\subsection{Materials}

The materials used in this work were divided into D. magna living media and food, such as ground water, baker's yeast and green water as well as the materials used to mix the toxicants, Tween- 80 and oil sludge postbiophytoremediation of 24 and 40 months.

\subsection{Methods}

This study applied the Completely Randomized Design (CRD) method. The test animals were D. magna neonates that were less than 24 hours old. The study was first started with preliminary Range Finding Test prior to initiate a static, acute, definitive toxicity test. The result of this test was the range between the upper and lower concentration limit which caused $50 \%$ death of test animals. The series of concentrations (within the tested range) in the acute test were determined using the logarithmic scale interval series table [9]. A total of 500 neonates were required to be placed randomly in five test chambers. The treatment given was five different concentrations, each repeated five times; each test chamber contained ten neonates. Neonates were separated from the mother two hours before the exposure. The number of living and dead individuals were noted in a logbook every 24 hour for four days in order to calculate the $\mathrm{LC}_{50}$ value. After 96 hours of exposure, the remaining living individuals were moved into a new media. The new media (a mixture of ground water, green water and baker's yeast) was prepared to observe the post acute test effect which was shown by the reproduction rate of the surviving animals. The reproduction test was held for 14-21 days, or long enough for the development of at least three broods. New offsprings from each test chamber must be counted and allocated every Monday, Wednesday and Friday.

The mortality rate of $D$. magna during the acute test period was analyzed with probit method using SPSS 26.0 program to calculate the $\mathrm{LC}_{50}$ value. Meanwhile, the reproduction rate was analyzed with ANOVA test of $5 \%$ significance level and was continued with the Duncan test. ANOVA and Duncan tests were analyzed with the XLSTAT 2019 program. The $\mathrm{LC}_{50}$ would be compared to the toxicity category of petroleum sludge according to [14].

Table 1. Toxicity Category of Petroleum Sludge (Swan et al., 1994)

\begin{tabular}{cc}
\hline Toxicity Category & LC $_{50}(\mathbf{9 6} \mathbf{~ h r}) \mathbf{p p m}$ \\
\hline Extremely toxic & $<1$ \\
Highly Toxic & 1 to $<100$ \\
Moderately toxic & 100 to $<1000$ \\
Lowly toxic & 1000 to $<10000$ \\
Slightly toxic & 10000 to $<100000$ \\
Non toxic & $>100000$ \\
\hline
\end{tabular}

You are free to use colour illustrations for the online version of the proceedings but any print version will be printed in black and white unless special arrangements have been made with the conference organiser. Please check whether or not this is the case. If the print version will be black and white only, you should check your figure captions carefully and remove any reference to colour in the illustration and text. In addition, some colour figures will degrade or suffer loss of information when converted to black and white, and this should be taken into account when preparing them.

\section{RESULTS AND DISCUSSION}

In this study, the toxicity of oil sludge postbiophytoremediation for 24 months $\left(\mathrm{OS}_{24}\right)$ and 40 months $\left(\mathrm{OS}_{40}\right)$ was tested to D. magna. The toxicity test consisted of the Range Finding Test (RFT) or the preliminary test that is required to find the upper and lower limit of oil sludge concentration that killed 50\% population of test animals. RFT was carried out for one day and it was discovered that the range for $\mathrm{OS}_{24}$ is between $1 \mathrm{ppm}-0,01 \mathrm{ppm}$ whereas the range for $\mathrm{OS}_{40}$ is between $1 \mathrm{ppm}-0,1 \mathrm{ppm}$. The upper and lower limit were used to determine the acute toxicity test $\left(\mathrm{LC}_{50}\right)$ and chronic test (reproduction) using the logarithmic scale interval series table [10]. The series of concentrations used for $\mathrm{OS}_{24}$ were $0.65,0.21,0.056,0.0135$ and $0 \mathrm{ppm}$ (control), whereas for $\mathrm{OS}_{40}$, the concentrations were $0.87,0.56,0.37,0.18$ and 0 (control).

\subsection{Acute Toxicity Test $\left(\mathbf{L C}_{50}\right)$}

Acute toxicity test was conducted to evaluate the effects inflicted by the test solutions $\mathrm{OS}_{24}$ and $\mathrm{OS}_{40}$ 
towards the death of $50 \%$ population of D. magna that were exposed for 96 hours. The results of $\mathrm{OS}_{24}$ and $\mathrm{OS}_{40}$ are represented by the average mortality of D. magna in each test solution and can be seen in Table 2 and Table 3.

Table 2. Average Mortality of D. magna in $\mathrm{OS}_{24}$ Test Solution

\begin{tabular}{|c|c|c|}
\hline No. & Test Solution Concentration (ppm) & Average Mortality (\%) \\
\hline 1 & 0.65 & 100 \\
\hline 2 & 0.21 & 78 \\
\hline 3 & 0.056 & 72 \\
\hline 4 & 0.0135 & 16 \\
\hline \multirow[t]{2}{*}{5} & 0 (control) & 10 \\
\hline & & $\mathrm{LC}_{50}=0.042 \mathrm{ppm}$ \\
\hline
\end{tabular}

Table 3. Average Mortality of D. magna in $\mathrm{OS}_{40}$ Test Solution

\begin{tabular}{ccc}
\hline No. & Test Solution Concentration (ppm) & Average Mortality (\%) \\
\hline 1 & 0.87 & 100 \\
2 & 0.56 & 84 \\
3 & 0.37 & 58 \\
4 & 0.18 & 26 \\
5 & 0 (control) & 10 \\
\hline & & LC $_{50}=\mathbf{0 . 3 6 6} \mathbf{~ p p m}$ \\
\hline
\end{tabular}

Table 2 and Table 3 show different ranges of average mortality. Based on the probit analysis, the $\mathrm{LC}_{50-96 \text { hours }}$ of $\mathrm{OS}_{24}$ is $0.042 \mathrm{ppm}$ (between $0.0135-0.65$ $\mathrm{ppm})$. According to Swan's toxicity category table, this value is considered very toxic since it is under $1 \mathrm{ppm}$. Likewise, the $\mathrm{LC}_{50^{-}} 96$ hours of $\mathrm{OS}_{40}$ is $0.366 \mathrm{ppm}$ (between $0.18-0.87 \mathrm{ppm})$. Both of these values are categorized as 'extremely toxic', but the $\mathrm{LC}_{50-96}$ hours value of $\mathrm{OS}_{24}$ is lower than $\mathrm{OS}_{40}$. This shows that the test solution of $\mathrm{OS}_{24}$ was more toxic than $\mathrm{OS}_{40}$. Moreover, these results explain that biophytoremediation could reduce toxicity in a period between 24 and 40 months, although the reduction rate is not too significant. A long-term bioremediation process is required to reduce the toxicity level of sludge-type pollutants in large amount. [8] stated that oil sludge is a complex emulsion which is cytotoxic, mutagenic and potentially carcinogenic. It also affects soil fertility. The use of microorganisms can transform pollutants to less-toxic compounds through composting processes. Nevertheless, the degradation of oil sludge will have to go through several complex remediation processes such as physical, chemical, and biological to reduce the toxicity level in a shorter period of time. Based on these facts, the oil sludge in this study must be treated further to decrease its toxicity.

Both $\mathrm{OS}_{24}$ and $\mathrm{OS}_{40}$ were still extremely toxic when they were tested to D. magna. The toxicants are categorized as extremely toxic and this is shown by the previous GCMS results. Nevertheless, the GCMS test showed that the compounds contained in $\mathrm{OS}_{40}$ had been splitted into simpler compounds when compared to the compounds that made up $\mathrm{OS}_{24}$. Oil sludge is basically a toxic, complex compound, thus in order to reduce its toxicity, a series of remediation processes are required to break the complex compounds into their constituents. The Environmental Literacy Council (2015) suggested that pollutants should be processed without producing residues and being harmful to the environment, hence bioremediation is highly recommended.

D. magna has been used widely to evaluate water body quality due to its sensitivity towards any toxicants in their living media [11]. [3] tested the toxicity of oil sludge waste before and after phytoremediation to
Daphnia carinata and the results showed that the $\mathrm{LC}_{50^{-}}$ 48 hours values of OS before and after phytoremediation are $28.62 \mathrm{ppm}$ and $126.55 \mathrm{ppm}$. Furthermore, [10] carried out a biophytoremediation process of oil sludge for 14.5 months and tested it to Rattus norvegicus. The result was categorized as 'low toxic' with a $\mathrm{LD}_{50}$ of $9.785,184 \mathrm{mg} / \mathrm{kg}$. D. magna use filtration mechanism to acquire food from their environment. Therefore, when they were exposed to harmful compounds, the substances do not only affect their digestive systems but also their entire body surface. Meanwhile, the mixture of oil sludge and rat feed needed more time to be digested in the digestive system of Rattus norvegicus. Thus, during the time that the toxicity tests were carried out, the toxic effects of the oil sludge were deadlier for D. magna. These comparisons explain that oil sludge has worse impacts towards aquatic organisms than to terrestrials.

\subsection{Chronic Toxicity Test (Reproduction)}

Chronic toxicity test was carried out to evaluate the effect caused by toxicants after the acute toxicity test. The observed parameters in this test were the decrease in the number of $D$. magna parents and offsprings produced during the test. These procedures were conducted based on the [16] guidelines.

\subsubsection{The Reduction of $D$. magna Parents}

The reduction in number of $D$. magna parents must be observed to evaluate the parents' viability after the acute toxicity test. The results of ANOVA analysis for this parameter are shown in Table 4 and Table 5.

Table 4. ANOVA Test Result towards The Reduction of $D$. magna Parents in $\mathrm{OS}_{24}$

Conclusion for D8 (ANOVA):

\begin{tabular}{lc} 
& $\mathrm{D} 8$ \\
\hline $\mathrm{R}^{2}$ & 0.133 \\
$\mathrm{~F}$ & 1.000 \\
$\mathrm{Pr}>\mathrm{F}$ & 0.397 \\
\hline
\end{tabular}

Table 5. ANOVA Test Results towards The Reduction of $D$. magna Parents in $\mathrm{OS}_{40}$

Conclusion for all Y (ANOVA):

\begin{tabular}{lll} 
& $\mathrm{D} 11$ & $\mathrm{D} 13$ \\
\hline $\mathrm{R}^{2}$ & 0.143 & 0.143 \\
$\mathrm{~F}$ & 1.000 & 1.000 \\
$\mathrm{Pr}>\mathrm{F}$ & 0.397 & 0.397 \\
\hline
\end{tabular}

Annotation: ANOVA table shows significance if (pr>F) value is less than 0,05

Table 4.6 and 4.7 showed that the results were insignificant. This insignificance explained that the number of parents were relatively constant in $\mathrm{OS}_{24}$ and $\mathrm{OS}_{40}$. In other words, the mortality rate was nearly zero. Throughout the chronic test, food was given periodically in accordance to the US EPA guidelines, thus nutrition from the food could sustain the parents' life. Food was 
given two hours before the acute toxicity test and was not given again during the 96-hour test for D. magna to signify effects that were purely caused by the oil sludge's toxicity. D. magna is known for its sensitivity and is able to show morphological and activity changes when exposed to particular toxicants [2]. During the acute toxicity test, D. magna showed their adaptations by reducing their activity in order to survive the foodlimited environment [17]. Afterwards, D. magna were moved to a food-provided environment to support their growth and development to prepare them for the chronic toxicity test. Each test animal had sufficient nutrition, thus reducing the competition between test individuals. This could also suggest that the exposure in the acute toxicity test was not toxic enough to affect the growth and development of D. magna in the chronic toxicity test.

\subsubsection{The Reduction of Offsprings Produced by D. magna}

The number of offsprings produced must be observed to evaluate the fertility of D. magna as it was one of the chronic effects shown after the exposure. The results of ANOVA analysis showed significance, hence the analysis was continued to Duncan test. The Duncan test results for the number of offsprings produced by $D$. magna are shown in Table 6 and Table 7

Table 6. Duncan Test Results for The Number of Offsprings Produced by D. magna in $\mathrm{OS}_{24}$

\begin{tabular}{lcccc}
\hline & D5 & D8 & D11 & D13 \\
\hline 0 & $1.000 \mathrm{a}$ & $69.600 \mathrm{a}$ & $44.000 \mathrm{a}$ & $26.000 \mathrm{a}$ \\
0.0135 & $0.000 \mathrm{a}$ & $87.200 \mathrm{a}$ & $38.600 \mathrm{a}$ & $21.000 \mathrm{ab}$ \\
0.056 & $0.000 \mathrm{a}$ & $3.200 \mathrm{~b}$ & $4.800 \mathrm{~b}$ & $6.000 \mathrm{~b}$ \\
\hline Pr $>$ F(Treatment) & 0.397 & $<0.0001$ & 0.001 & 0.041 \\
Significant & No & Yes & Yes & Yes \\
\hline
\end{tabular}

Table 7. Duncan Test Results for The Number of Offsprings Produced by D. magna in $\mathrm{OS}_{40}$

\begin{tabular}{lcccc}
\hline & D5 & D8 & D11 & D13 \\
\hline 0 & $8.0 \mathrm{a}$ & $66.2 \mathrm{a}$ & $63.0 \mathrm{a}$ & $11.4 \mathrm{a}$ \\
0.18 & $1.0 \mathrm{a}$ & $57.0 \mathrm{a}$ & $64.8 \mathrm{a}$ & $19.8 \mathrm{a}$ \\
0.37 & $1.0 \mathrm{a}$ & $22.0 \mathrm{a}$ & $28.4 \mathrm{a}$ & $24.6 \mathrm{a}$ \\
\hline Pr $>$ F(Treatment) & 0.062 & 0.003 & 0.006 & 0.253 \\
Significant & No & Yes & Yes & No \\
\hline
\end{tabular}

Annotation: The Duncan table shows significance if $(\mathrm{pr}>\mathrm{F}$ ) value is less than 0,05

According to the Duncan analysis results, the number of offsprings produced by D. magna throughout the chronic toxicity test in $\mathrm{OS}_{24}$ and $\mathrm{OS}_{40}$ showed significance starting from day 8 because every parent in each test chamber had produced offsprings. However, the parents were 4 days old when they were moved to the new chamber for the chronic toxicity test and were 12 days old when they all produced the first offprings. This is due to the fact that $D$. magna generally could produce offsprings in the age of 4 days as they reach maturity quickly [6]. If the optimum condition is provided, D. magna could produce as many as 4-22 eggs per day. During the chronic toxicity test, the reproduction rate of D. magna is assumed to be delayed due to the toxic effect from the exposure of test solutions $\left(\mathrm{OS}_{24}\right.$ and $\left.\mathrm{OS}_{40}\right)$ in the previous acute toxicity test. Nonetheless, the test organisms did not produce ephippia or resting eggs. [2] stated that D. magna will produce dormant, sexual eggs when exposed under stressful environment as these eggs can withstand heat, cold, lack of oxygen and nutrition, fluctuations in the population and drought. Ephippia was formed sexually to produce genetic variation and increase the chance of species survival. Therefore, the absence of ephippia in this test signify that $D$. magna had enough nutrition after the exposure, hence the toxic effect did not affect the formation of the asexual eggs. Still, the egg formation was delayed. This fact explains that $\mathrm{OS}_{24}$ and $\mathrm{OS}_{40}$ gave significant effect to the reproduction of D. magna.

The data on Table 6 and 7 showed that the lowest increase of offsprings was in the concentration 0.056 of $\mathrm{OS}_{24}$ and 0.37 of $\mathrm{OS}_{40}$. Oil sludge affected the reproduction of D. magna chronically, thus the offsprings produced were lesser than in other concentrations. In the test solutions of $\mathrm{OS}_{40}$, the number of offsprings produced in day 13 was not significant. This might be caused by the microorganisms' activities living in the media. They broke down organic matters in the media which resulted in the formation of carbon dioxide. The increase of carbon dioxide caused the water's $\mathrm{pH}$ to decrease, thus some compounds (such as ammonia) in the water became toxic. This could lead to a decrease in the number of offsprings produced in the media [1].

The negative effects that occurred in the test organisms of this study indicate that the use of oil sludge is really harmful to the environment, especially heavy metals that are contained in the toxicants. According to the GCMS test, the heavy metals in oil sludge are $\mathrm{Pb}$ (lead), $\mathrm{Ni}$ (nickel), Cd (cadmium), $\mathrm{Cr}$ (chromium), and $\mathrm{Hg}$ (hydragyrum/mercury). These heavy metals are able to induce toxic effects that harm the physiological function of the exposed organisms. Other than that, there were originally 9 compounds of hydrocarbons in $\mathrm{OS}_{24}$. After $\mathrm{OS}_{24}$ underwent the biophytoremediation process for 40 months, 4 out of 9 compouds were degraded into 93 simpler compouds. The compounds that were not degraded consisted of hexane, cyclopentane, cyclohexane, decane and cyclohexasiloxane. This proved that biophytoremediation can break down oil sludge into less toxic forms. According to the analysis of both acute and chronic toxicity test data in this study, the process of oil sludge degradation requires a longer period of time in order to fully remove its toxic characteristics, mainly in aquatic environment.

As it was mentioned previously, the toxicity of oil sludge is more harmful to aquatic organisms than it is to terrestrial organisms. Based on this comparison, the toxic effects have to be known widely for many different types of test animals. Therefore, the toxicity of oil sludge must be tested towards multilevel organisms and various oil sludge's impacts will be discovered for various ecosystems.

\section{CONCLUSION}

Based on the explaination above, the $\mathrm{LC}_{50}$ values for both $\mathrm{OS}_{24}$ and $\mathrm{OS}_{40}$ are $0.0149 \mathrm{ppm}$ and $0.2844 \mathrm{ppm}$ respectively. Both values are considered extremely toxic. The test solutions $\mathrm{OS}_{24}$ and $\mathrm{OS}_{40}$ slowed the reproduction rate of $D$. magna. A concentration of 0.056 ppm $\mathrm{OS}_{24}$ and 0.37 ppm $\mathrm{OS}_{40}$ had the largest effect on 
D. magna in which the average number of offsprings produced were less than the ones produced in other treatments.

\section{References}

1. Azizah, D, Kajian Kualitas Lingkungan Perairan Teluk Tanjungpinang Provinsi Kepulauan Riau, Dinamika Maritim, 6 (1): 47-53 (2017)

2. Deken, A, Seeing Red: Daphnia and Hemoglobin, Missouri: Washington University (2005)

3. Kasmara, H., N. Rossiana, dan A. S. Achwani, Uji Toksisitas Lumpur Minyak Bumi Sebelum dan Sesudah Fitoremediasi dan Pengaruhnya terhadap Reproduksi Daphnia carinata King, Jurnal Biotika. 4 (1): 18-23.

4. Li, L., B. Zheng, and L. Liu, Biomonitoring and Bioindicators Used for River Ecosystems: Definitions, Approaches and Trends. Energy Policy - ENERG POLICY, Procedia Environmental Sciences, 2: 1510-15242. 15101524. 10.1016/j.proenv.2010.10.164 (2010)

5. OECD (Organisation for Economic Co-operation and Development), Daphnia sp., Acute Immobilisation Test and Reproduction Test. OECD Guideline for Testing of Chemicals (1984)

6. Pangkey, H, Daphnia dan Penggunaannya. Jurnal Perikanan dan Kelautan, 5 (3): 33-36 (2009)

7. Poirier, D. G., G. F. Westlake, and S. G. Abernethy, Daphnia magna Acute Lethality Toxicity Test Protocol, Ontario: Ontario Ministry of the Environment (1988)

8. Prakash, V., S. Saxena, A. Sharma, S. Singh, and S.K. Singh, Treatment of Oil Sludge Contamination by Composting, Journal of Bioremediation \& Biodegradation. 6 (3): 1-6). DOI: 10.4172/2155-6199.1000284 (2015)

9. Rand, M. C., A. E. Greenberg, and M. J. Taras, Standard methods for the examination of water and wastewater. $14^{\text {th }}$ edition. ISBN: 0875530788. Washington, DC: American Public Health Association (1976)

10. Rossiana, N, Penurunan Kandungan Logam Berat dan Pertumbuhan Tanaman Sengon (Paraserianthes falcataria L (Nielsen) Bermikoriza dalam Medium Limbah Lumpur Minyak Hasil Ekstraksi, Sumedang: Universitas Padjadjaran (2006)

11. Santos-Medrano, G. E. and R. Rico-Martinez, Acute Sensitivity Comparison among Daphnia magna Straus, 1820 Daphnia pulex Leydig,1860 and Simocephalus vetulus, 1776, Exposed to Nine Toxicants. Turkish Journal of Fisheries and Aquatic Science, 19 (7): 615-623 (2017)

12. Siciliano, A., R. Gesuele, G. Pagano, and M. Guida, How Daphnia (Cladocera) Assays may be used as Bioindicators of Health Effects?. Journal of Biodiversity \& Endangered Species. 10.4172/2332-2543.S1.005 (2015)

13. Sudarso, Y., T. Suryono, G.P. Yoga, Penyusunan Biokriteria dengan menggunakan Konsep Multimetrik: Studi Kasus Anak Sungai Cisadane. Jurnal Oseanologi dan Limnologi di Indonesia. 35 (2):180- 181 (2009)

14. Swan, J. M., J. M. Neff, and P. C. Young, Environmental Implications of Offshore Oil and Gas Development in Australia. The Finding of an Independent Scientific Review. Sydney: Australian Petroleum Exploration Association (1994)

15. Ubani, O., H.I. Atagana, and M.S. Thantsha, Biological degradation of oil sludge: A review of the current state of development, African Journal of Biotechnology. 12 (47): 6544-6567 (2013)

16. US EPA (United States Environmental Protection Agency), Methods for Measuring the Acute Toxicity of Effluents and Receiving Waters to Freshwater and Marine Organism. Fifth Edition. EPA-821-R-02-012. Office of Water (43035), Washington DC: US EPA (2002)

17. White, T.C.R, The Importance of a Relative Shortage of Food in Animal Ecology, Oecologia (Berl.). 33: 71-86 (1978) 